DE DE GRUYTER

OPEN
Journal of Intercultural Management

Vol. 6, No. 4, December 2014, pp. 5-23

DOI 10.2478/joim-2014-0032

Aldona Glińska-Neweś*
Nicolaus Copernicus University in Toruń

Pieter van Nispen*

Rotterdam University of Applied Sciences

\title{
How We Do Things Around Here. The Polish-Dutch Comparison Of The University Organisational Culture
}

\begin{abstract}
Analyses and international comparisons of university organisational cultures are rare or even non-existing in management studies. Our paper fills this gap, presenting the results of a pilot study conducted in two units representing a Polish and a Dutch university. The survey has been carried out on a basis of a model and a measuring tool created by the Dutch researcher Aldert P. Dreimüller. Using two dimensions of change tolerance vs. control; and internal vs. external orientation he proposed a typology of four organisational cultures: task, aim, team and process culture. Each type is described with the same set of criteria. The types identified in the course of our survey are interpreted through the lens of the national cultures of the Netherlands and Poland. However, the main result of the study, and thus the main aim of this paper, is a multi-faceted usage and test of the Dreimüller's tool.
\end{abstract}

Key-words: organisational culture, university, Dreimüller, Poland, the Netherlands

\section{Introduction}

The complementarity of culture and organisations is getting more and more recognised, ranging from doing business abroad through multicultural society to organisational culture. Yet, the progress in application is slow, due to, amongst others, the lack of ready-to-use reliable instruments. Business needs practical tools, not a series of trainings, exceptions and disclaimers. As early as in 1992 Martin said

*ajka@econ.umk.pl; p.nispen@ziggo.nl 
"Given this conceptual chaos, it is no wonder that researchers adopt simplifying theoretical perspectives, fail to appreciate (or even read) research conducted within other perspectives, and argue about incommensurabilities" [Martin J., 1992, p. v].

This paper focuses on organisational culture and demonstrates a practical tool referring to a typology, which may be useful in an organisational culture analysis and comparisons. Like other tools it is only a starting point for a more detailed discussion of the organisational culture of the institution in question and the ways and means of changing it, if necessary. However, it is also a recent tool, the result of a Dutch PhD thesis and one of the few, based on the European research. Laying emphasis on the European research is of importance because national values give a specific, national bias in favour of certain values in research on organisational culture, whether we like it or not. The American research is biased by American values and would not be fully applicable in a European context. In business, this idea is reinforced by the different economic systems with their different orientations on e.g. shareholders, customers and management.

Organisational culture is of importance for an institution's survival, effectiveness and efficiency. It is of importance for how people are doing their job without much supervision (soft controls), the relationships with stakeholders and the health and turnover of personnel (more satisfied by working in the right place). It has a strong relation with strategy, structure and control (see for instance Hofstede 2010, p. 372). As such it should be analysed in relation to every kind of organisation regardless it's sector, domain or size. Organisational culture studies regarding universities are very rare or even non-existing. According to our knowledge this limited number of contributions focuses rather on the contemporary situation and the role that is played by higher education institution in the global economy [see Chaput C., 2008; Gipp G.E., Warner L.S., 2009] than on the analyses of specific university organisational culture. It may be concluded then that the shoemaker's children are ill-shod. Our paper tries to fill this gap. However, the inspiration to write it was born on the basis of our long-term cooperation and inevitable comparisons of the policies and practices of the Polish and the Dutch university.

We start our presentation with the nature of organisational culture and general problems referring to the organisational culture measurement and classification, however without going into detail. Then we go on to the presentation of our survey core theoretical background which is Dreimüller's organisational culture typology. The further paragraphs show a method used in the survey, samples and the survey results, respectively for the Polish and the Dutch respondents. The paper ends with discussion and implications for future research.

\section{Organisational culture. Theory and practice}

The quest for understanding organisational culture, leave alone a relevant instrument for business already has continued for half a century but has proven 
rather elusive. The research is a maze of disciplines, inductive-deductive, theories, methods, empirical testing, concepts, perspectives, axes, typologies, divergence and diversity, colours, observations, descriptions, interviews, questionnaires, aspects, games, change, functions and use, enculturation, relation with climate, strong and weak cultures, industry cultures, occupational cultures, project cultures and more. Not surprisingly, this maze results in insufficient exchanges between researchers, countries and disciplines.

The shortest definition of culture is following: culture is an institution [Vroom, 2002, p. 197]. For a sociologist an institution is a way of thinking, acting and feeling. Culture then becomes a way of thinking, acting and feeling. Because sociology studies groups of the people, an institution, and hence a culture, belongs to a group of people (e.g. the organisation) and is further delineated by a given time and place. Hofstede defines it as "the collective programming of the mind that distinguishes the members of one organization from others", also in the mind of stakeholders [Hofstede G., 2010, p. 344]. However, as Schein says "a chronic issue in conceptualizing 'culture' seems to be whether we should think of culture as a 'state' or static property of a given group/organization or as a human process of constructing shared meaning that goes on all the time" [Schein E., 2000, p.XXIV] and in the latter case may be used in a deliberate way.

Another important discussion ranges from the importance of values to a focus on practices. Hofstede stresses the latter position and it is also an outcome of GLOBE: "Results of the GLOBE Project to date suggest that national culture tends to reflect values, whereas organizational culture tends to reflect practices" [Ashkanasy N.M., Wilderom C.P.M. and Peterson M.F, 2000, p.386]. Looking at one aspect of values research underlines this position. Values are developed in the pre-adult years and for that reason they do not develop or change once they start working. From that perspective organisational culture is the rather specific mix and interaction (practices) of values of the employees that are linked to a national culture values. At the same time, organisational practices may be more difficult to research, more time consuming (interviews, observations) and less easy to compare (unique nature). According to Martin Hofstede: "Societies, organizations, and individuals represent the gardens, bouquets, and flowers of social science. Our research has shown that the three are related and part of the same social reality. If we want to understand our social environment, we cannot fence ourselves into the confines of one level only: we should be prepared to count with all three" [2010, p. 368].

\section{Classifying and Measuring Organisational Culture}

Every organisational culture is to some extent unique and unrepeatable, however there is still a need for categorisation of this variety, both for scientific reasons and use in business practice. A few approaches have received particular interest in management studies. 
In the classic approach proposed by Harrison [1972] and elaborated by Handy [1978] the types of organisational culture (power, role, task and person) are related to the two dimensions of centralisation and organisation formalisation. Although rather simple, the approach has been extremely influential and is playing a primary role in shaping the way in which scholars, students and practitioners understand the work environment [Brown 1998, p. 66]. Interestingly, another popular and significant classification of organisational cultures created by Deal and Kennedy [1982] led to the relatively similar results. Although based on the different dimensions (i.e. the company's activity degree of risk and feedback speed) and proposed labels of culture types are more colourful than in the previous typology (the tough-guy - macho culture, work hard/play hard culture, bet-your-company culture, process culture) the essence of each type may be identified with Harrison/Handy's approach. To some extent the analogy may be found in the next leading concept created by Cameron and Quinn [2006]. They developed a model of competing values. Their research started with a list of 39 possible indicators of organisational effectiveness but through statistical analyses brought these 39 down to two dimensions (flexibility vs. control and internal vs. external orientation) and four clusters.

The aforementioned proposals discuss organisations but actually talk about companies, not NGO's or governments. Furthermore, they do not refer to the values research and hence, their statement that the culture clusters represent values is an assumption. They note, however that the literature indicates how organisational values have been associated with forms of organisations (possibly only in a US context). They state that the (unproven) strength of the clusters identified in every approach (four clusters in each) defines them as four cultural types. Thirdly, none of those approaches fully explain their starting point, i.e. the selection of axes or dimensions. Why just two dimensions/axes (e.g. internal-external and change-control) and why these two? Other researchers come up with other dimensions and/ or with more than two (up to seven) [see culture dimensions proposed by Trompenaars and Hampden-Turner 1997 and Schwartz 1992]. Nevertheless, each of them is declared as the key starting point for understanding organisational culture. If so, they would be all related and a two dimensional approach would be superficial.

As an attempt to overcome these simplifications the Hofstede organisational culture model [based on the work by Sanders and Neuijen 2005] recognises six autonomous and two semi-autonomous dimensions. The inductive research is based on interviews in 20 units of 10 companies in the Netherlands and Denmark. However, the application is commercially protected [description in Hofstede 2010, details not in the public domain]. 


\section{Dreimüller's Organisational Culture Typology}

As mentioned before, in this paper we not only contribute to the university organisational culture analyses but also make a pilot usage of Dreimüller's approach to measure/identify it. Dreimüller took the policy cycle and the improvement of the organisation as his starting points. The policy cycle consists of the development of strategy, measuring it through the balanced scorecard (BSC) and implementation. The BSC originally focuses on the primary and secondary processes, each with two aspects, one of which may be related to production and tasks and the other to means and society. Dreimüller converts the BSC into a typology of four cultures(figure 1), each of them described along the same set of criteria (including core of the culture and approach to systems, to making mistakes, staff, organisation, communication, success, management style and danger). Although the axes are very similar to those in the Quinn/Cameron's approach, both the items constituting each culture type and culture types' descriptions are different.

Figure 1: Dreimüller's organisational culture typology

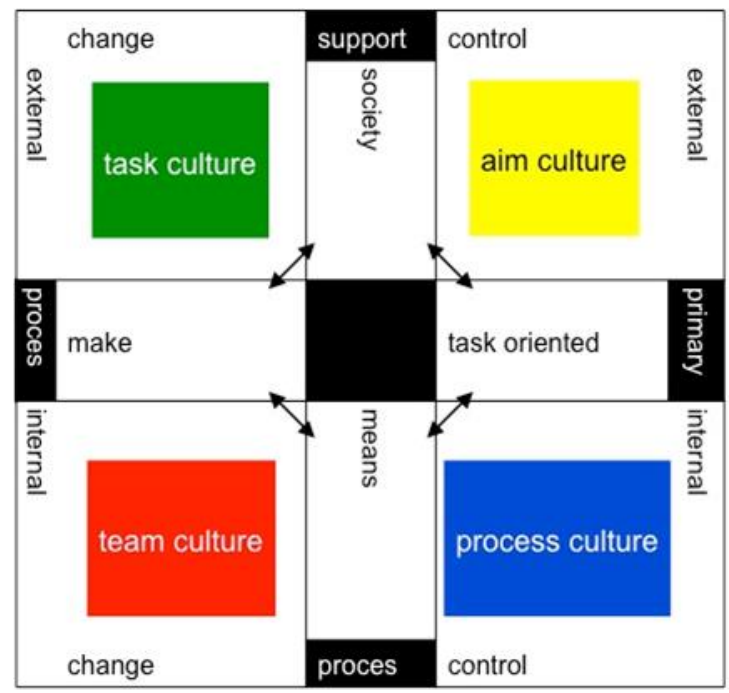

Source: own work.

The four cultures are described in catchwords in the table below (Table 1.). 
Table 1. Organisational cultures types according to Dreimüller

\begin{tabular}{|c|c|c|c|c|}
\hline Criteria & Task culture & Aim culture & Team culture & Process culture \\
\hline Core & Activities & Results & Adaptation & $\begin{array}{l}\text { Systems, rules } \\
\text { and procedures }\end{array}$ \\
\hline Approach & $\begin{array}{l}\text { The method, } \\
\text { the objective } \\
\text { becomes clear } \\
\text { while doing } \\
\text { the job }\end{array}$ & Use people effectively & $\begin{array}{l}\text { Work tuned to } \\
\text { employee }\end{array}$ & $\begin{array}{l}\text { Formalised reali- } \\
\text { sation of objec- } \\
\text { tives }\end{array}$ \\
\hline Systems & $\begin{array}{l}\text { Adapting rules } \\
\text { and proce- } \\
\text { dures }\end{array}$ & $\begin{array}{l}\text { Rules and procedures } \\
\text { depending on objec- } \\
\text { tive }\end{array}$ & $\begin{array}{l}\text { Broad interpre- } \\
\text { tation of rules } \\
\text { and procedures }\end{array}$ & $\begin{array}{l}\text { Optimizing rules } \\
\text { and procedures }\end{array}$ \\
\hline Mistakes & $\begin{array}{l}\text { Allows mak- } \\
\text { ing mistakes }\end{array}$ & Failures do not exist & $\begin{array}{l}\text { Improved, not } \\
\text { punished }\end{array}$ & $\begin{array}{l}\text { Preventing struc- } \\
\text { tural mistakes }\end{array}$ \\
\hline Staff & $\begin{array}{l}\text { Curious, inno- } \\
\text { vative }\end{array}$ & $\begin{array}{l}\text { Obedient, carry out } \\
\text { instructions }\end{array}$ & Not controlled & Controlled \\
\hline Organisation & $\begin{array}{l}\text { Initiative, } \\
\text { freedom, } \\
\text { egalitarian, } \\
\text { informal }\end{array}$ & $\begin{array}{l}\text { Logical whole on basis } \\
\text { of power }\end{array}$ & $\begin{array}{l}\text { Security and } \\
\text { consensus }\end{array}$ & $\begin{array}{l}\text { Impersonal, no } \\
\text { individual free- } \\
\text { dom, controls, } \\
\text { provides security }\end{array}$ \\
\hline Communication & Open & One-way traffic & Negotiations & $\begin{array}{l}\text { Set down re- } \\
\text { sponsibilities, } \\
\text { measuring and } \\
\text { documentation }\end{array}$ \\
\hline Success & New products & Market share & Care for people & Routine \\
\hline $\begin{array}{l}\text { Management } \\
\text { style }\end{array}$ & $\begin{array}{l}\text { Innovator, } \\
\text { mediator, tak- } \\
\text { ing risk }\end{array}$ & Producer and manager & $\begin{array}{l}\text { Mentor and } \\
\text { stimulator }\end{array}$ & $\begin{array}{l}\text { Controller and } \\
\text { coordinator }\end{array}$ \\
\hline Key & $\begin{array}{l}\text { Creativity, } \\
\text { improvisa- } \\
\text { tion, future } \\
\text { directed }\end{array}$ & $\begin{array}{l}\text { Position, winning, } \\
\text { effective }\end{array}$ & $\begin{array}{l}\text { Teamwork, } \\
\text { trust, loy- } \\
\text { alty, preventing } \\
\text { conflicts, the } \\
\text { human being }\end{array}$ & $\begin{array}{l}\text { Process, ratio, } \\
\text { plans }\end{array}$ \\
\hline Examples & $\begin{array}{l}\text { R\&D de- } \\
\text { partments, } \\
\text { advertising } \\
\text { agencies, } \\
\text { investment } \\
\text { companies }\end{array}$ & $\begin{array}{l}\text { Police stations, mar- } \\
\text { keting departments, } \\
\text { operation theatres }\end{array}$ & $\begin{array}{l}\text { Retail trade, } \\
\text { group practices }\end{array}$ & $\begin{array}{l}\text { Insurance com- } \\
\text { panies, govern- } \\
\text { ment }\end{array}$ \\
\hline Danger & $\begin{array}{l}\text { Pursuing a } \\
\text { hobby }\end{array}$ & Compartmentalization & Anarchy & Bureaucracy \\
\hline
\end{tabular}

Source: Dreimüller 2008b 
On the basis of his $\mathrm{PhD}$ thesis Dreimüller developed a questionnaire, a website and a game [Dreimüller 2008a, 2008b]. Again, they are only the starting point of further discussions and they do result in a straightforward picture. Organisations generally have a dominating culture but also include aspects of other cultures. In the next paragraph we present results of the Dreimüller questionnaire application in two university units within the Polish and the Dutch culture. One of the aims of this study was to test the research tool in a multi-faceted way and for that reason the questionnaire was used in different manner in each organisation. However, results of both surveys indicate elements of the analysed units' organisational cultures and as such may serve as the basis for comparisons as well as suggestions for the universities management.

\section{Method}

The questionnaire, originally created in Dutch has been translated into English and then into Polish. The list of items included in the questionnaire is presented in an appendix. These items (statements) are grouped in four areas: the organisation, the management, the people and the decision-making. Each area consists of four sets of four statements each, representing four types of culture. Each time a respondent needs to divide 10 points over four statements. In our approach we have modified the original approach by asking the Polish respondents for a double assessment: the existing organisational culture and the desired one. This was done to find out whether the results differ and if respondents may cope with such a double assessment. It is also in line with two different ways of playing the related game. The answers were processed as follows:

1. For each statement the average score was calculated.

2. The average score for each culture type (team, task, aim, process) was calculated for each area (the organisation, management, people, decision making).

3. All four areas' results are gathered together and the average score for each culture type was calculated.

In the Polish university unit the survey was conducted in September 2014. The questionnaire was sent to all (i.e. 115) academic staff and 43 responses have been collected, which represents almost $40 \%$ of the population. In relation to the aim of the research (a multi-faceted test of tool) the arithmetic mean for the whole sample was calculated.

Simultaneously, at the Dutch university groups of fourth year students of business administration, selected according to their participation in courses on organisational culture, made a survey (combination of playing the game and discussions) to get an idea of their university unit culture, obtaining perceptions of lecturers, management and students. Their results do not stand the test of scientific rigour (representative samples, numbers of respondents etc.), but they do give impressions 
about possible results variation according to a sub-culture. In the analysis of this part of the data we compare results of each respondent group as well as results gained by each group of students.

\section{Sample}

The analysed organisations are similar concerning their size and, obviously, the domain.

The Dutch university is a relatively large organisation with 34,000 students, 3,500 staff and 13 educational institutes. The institutes have key decision-making powers and the primary financial authority. The research has been conducted in the Institute of Management Studies.

The Polish university comprises of 17 faculties and 84 teaching programmes with 30,000 students and 4,300 employees including 2,200 teaching staff. The university governance has been decentralised recently and faculties received more decision-making powers. The idea of the organisational culture evaluation was met with a very positive reaction of a dean of the Faculty of Economics and Management. The results of the survey will be used in process of the faculty international certification.

\section{Results: the Polish university unit}

The survey has provided us with a multiplicity of data. In fact each of the 16 sets may be analysed separately delivering very interesting substance for in-depth study of the university organisational culture. However, considering the limited capacity of this paper we decided to present the final results reflecting the overall perception of existing and desired organisational culture as well as the most distinct scores in each analysed area; see figure 2 .

Figure 2. Present and desire organisational culture of the Polish university unit in the assessment of the academic staff

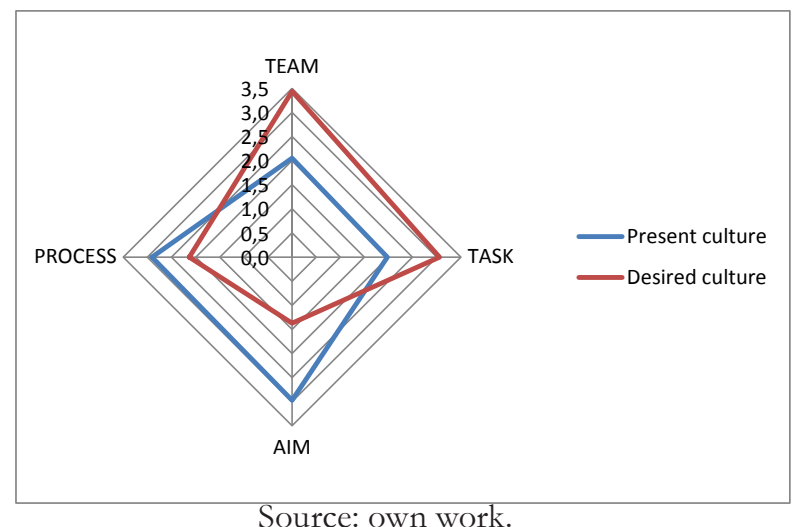

Source: own work. 
Average assessment of the statements in all four areas leads to the observation that the existing culture is a mixture of the process and aim type while the desired one comprises of elements of the task and team culture. As such this picture must be supplemented by the data regarding the specific area and statements. Table 2, therefore, presents the average scores of the highest evaluated statements for the existing and the desired culture in each statement set.

Table 2. The highest average scores for statements describing each category of the

\begin{tabular}{|c|c|c|c|}
\hline Area & Statemexisting and desired culture of the Polish university uni & $\begin{array}{l}\text { Culture } \\
\text { Type }\end{array}$ & $\begin{array}{l}\text { Average } \\
\text { score }\end{array}$ \\
\hline \multirow{8}{*}{ 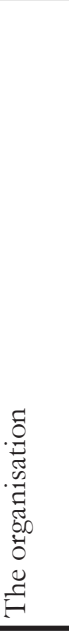 } & $\begin{array}{l}\text { Existing: The organisation is structured, formal rules and proce- } \\
\text { dures and strict management are characteristic. }\end{array}$ & Process & 3,4 \\
\hline & $\begin{array}{l}\text { Desired: The organisation is dynamic. Risks are taken, entrepre- } \\
\text { neurship may be noticed. }\end{array}$ & Task & 3,1 \\
\hline & $\begin{array}{l}\text { Existing: The organisation is mainly focused on rules, procedures, } \\
\text { efficient production and maintaining the status quo. }\end{array}$ & Process & 4,1 \\
\hline & $\begin{array}{l}\text { Desired: The organisation is mainly focused on collegiality, safety, } \\
\text { transparency and involvement in the objective of the organisation }\end{array}$ & Team & 4,0 \\
\hline & $\begin{array}{l}\text { Existing: The success of the organisation is determined by person- } \\
\text { nel development through involvement of and care for people. }\end{array}$ & Team & 3,2 \\
\hline & $\begin{array}{l}\text { Desired: The success of the organisation is determined by person- } \\
\text { nel development through involvement of and care for people. }\end{array}$ & Team & 3,7 \\
\hline & $\begin{array}{l}\text { Existing: The organisation treats people in the organisation as } \\
\text { employees with a contract and mutual rights and duties. }\end{array}$ & Process & 4,0 \\
\hline & $\begin{array}{l}\text { Desired: The organisation treats people in the organisation as } \\
\text { equals who unanimous aim at a common goals. }\end{array}$ & Task & 4,3 \\
\hline \multirow{8}{*}{ 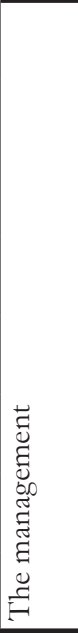 } & $\begin{array}{l}\text { Existing: The management of the organisation does not like non- } \\
\text { sense, is aggressive and wants to realise objectives. }\end{array}$ & Aim & 3,0 \\
\hline & $\begin{array}{l}\text { Desired: The management of the organisation guides, supports, } \\
\text { stimulates, facilitates and cares for employees }\end{array}$ & Team & 4,1 \\
\hline & $\begin{array}{l}\text { Existing: The management is expected to be strong and decisive, } \\
\text { hard but just. }\end{array}$ & Aim & 3,0 \\
\hline & $\begin{array}{l}\text { Desired: The management is expected to listen, to start the dialogue } \\
\text { and to be open for ideas of employees. }\end{array}$ & Task & 3,0 \\
\hline & $\begin{array}{l}\text { Existing: The management focuses on external and internal compe- } \\
\text { tition, high demands, efforts and results. }\end{array}$ & Aim & 2,7 \\
\hline & $\begin{array}{l}\text { Desired: The management focuses on strong mutual relations, team- } \\
\text { work, consensus and participation. }\end{array}$ & Team & 3,2 \\
\hline & $\begin{array}{l}\text { Existing: You may say to another what needs to happen if the other } \\
\text { has asked for help, guidance or advice. }\end{array}$ & Team & 4,2 \\
\hline & $\begin{array}{l}\text { Desired: You may say to another what needs to happen if the other } \\
\text { has asked for help, guidance or advice. }\end{array}$ & Team & 4,5 \\
\hline
\end{tabular}




\begin{tabular}{|l|l|l|l|}
\hline & $\begin{array}{l}\text { Existing: People need to give priority to the implementation of their } \\
\text { tasks within the existing rules and procedures. }\end{array}$ & Process & 3,1 \\
\hline $\begin{array}{l}\text { Desired: People need to give priority to the common implementa- } \\
\text { tion of tasks and the mutual support in doing so. }\end{array}$ & Team & 3,4 \\
\hline $\begin{array}{l}\text { Existing: People performing well are those who implement their work } \\
\text { within the system according to the prevalent rules. }\end{array}$ & Process & 3,2 \\
\hline $\begin{array}{l}\text { Desired: People performing well are those who are professionals and } \\
\text { want to get the job done }\end{array}$ & Task & 4,0 \\
\hline $\begin{array}{l}\text { Existing: Employees are expected to be hard working, obedient and } \\
\text { loyal to the management. }\end{array}$ & Aim & 3,4 \\
\hline $\begin{array}{l}\text { Desired: Employees are expected to good team players and have good } \\
\text { contacts with one another. }\end{array}$ & Team & 3,4 \\
\hline $\begin{array}{l}\text { Existing: People are motivated by their own motivation, the wish to } \\
\text { contribute and by thinking of improvements. }\end{array}$ & Task & 3,7 \\
\hline $\begin{array}{l}\text { Desired: People are motivated by their own motivation, the wish to } \\
\text { contribute and by thinking of improvements. }\end{array}$ & Task & 4,2 \\
\hline & $\begin{array}{l}\text { Existing: Decisions are taken on the basis of orders and instructions } \\
\text { by the management. }\end{array}$ & Aim & 3,7 \\
\hline $\begin{array}{l}\text { Desired: Decisions are the result of agreement, acceptance and sup- } \\
\text { port by the employees }\end{array}$ & Team & 3,7 \\
\hline $\begin{array}{l}\text { Existing: If rules and procedures are getting in the way they are vio- } \\
\text { lated if one has the power to do so or does not expect punishment. }\end{array}$ & Aim & 3,5 \\
\hline $\begin{array}{l}\text { Desired: If rules and procedures are getting in the way people support } \\
\text { one another by a wider interpretation of the rules and procedures. }\end{array}$ & Team & 5,3 \\
\hline $\begin{array}{l}\text { Existing: The assignment of tasks or works is based upon the plans } \\
\text { of the organisation in accordance with the existing rules. }\end{array}$ & Process & 4,1 \\
\hline $\begin{array}{l}\text { Desired: The assignment of tasks or works is based upon the per- } \\
\text { sonal preferences of the employee (career) and in consultation. }\end{array}$ & Team & 3,1 \\
\hline $\begin{array}{l}\text { Existing: Conflicts are normally avoided by referring to rules, pro- } \\
\text { cedures and responsibilities. }\end{array}$ & Process & 3,6 \\
\hline $\begin{array}{l}\text { Desired: Conflicts are normally solved by discussions, aimed at find- } \\
\text { ing win-win solutions. }\end{array}$ & Task & 3,9 \\
\hline \\
\hline
\end{tabular}

Source: own study

Both the general picture and the more detailed results in Table 2 show that the academic staff of the Polish university unit regards the organisational culture as control rather than change oriented. In reference to the organisation's internal environment, analysed in the questionnaire with the areas of 'the organisation' and 'the people', respondents consider the rules and procedures as the key means shaping the performance, also indicating the internal orientation in these two fields. In respect to the areas of 'management' and 'decision-making' the response suggests, however, a combination of control and external orientation. Specifically, the unit staff considered the management as rather centralized, demanding employee 
loyalty, obedience and hard-working but simultaneously focused on satisfying the superiors (in default: the university governance; this fact could be interpreted as leftovers of the previous centralized university system).

The answers given in reference to the desired organisational culture suggest, on the contrary, a preferred direction of change. The unit academic staff prefers an orientation on change and external environment. That means more focus on positive relationships at work, job satisfaction and team-work, accompanied by entrepreneurship and innovation. Only in case of two items the existing and desired cultures meet, i.e. in a definition of organisation success and staff motivation.

\section{Results: the Dutch university unit}

Figure 3 shows the organisational culture of one of the Institute of Management Studies, divided in the perceptions of students, lecturers and management. The research was done by using the game and interviewing people. Overall, the three groups have a more or less similar perception. Lecturers stress a more team oriented organisational culture. All three groups appear not to be interested in the aim culture.

Figure 3. The Dutch university unit organisational culture in the perception of students, lecturers and management

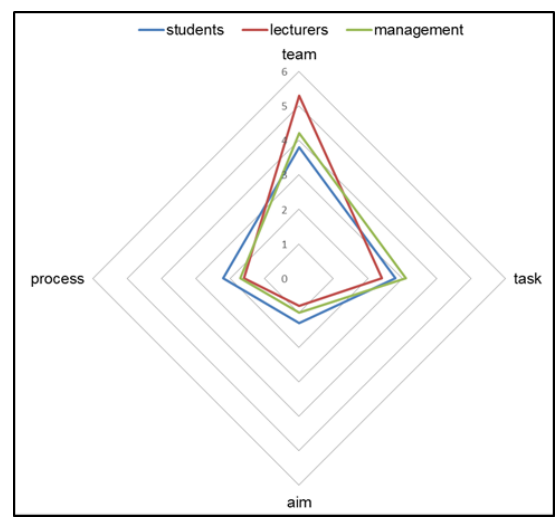

Source: own work.

Two other groups of the fourth-year BA students had quite different perceptions of the organisational culture. In order to compare with others, a junior researcher and a senior lecturer researcher were asked to add their perceptions (figure 4). The four diagrams stress the aim culture, just the opposite of its non-importance of figure 3. Three out of four stress a task-oriented culture. The importance of a team-culture was mostly mentioned by the junior researcher. The main focus for the students was either a process or an aim-culture. 
Figure 4. Different perceptions of the Dutch university unit organisational culture

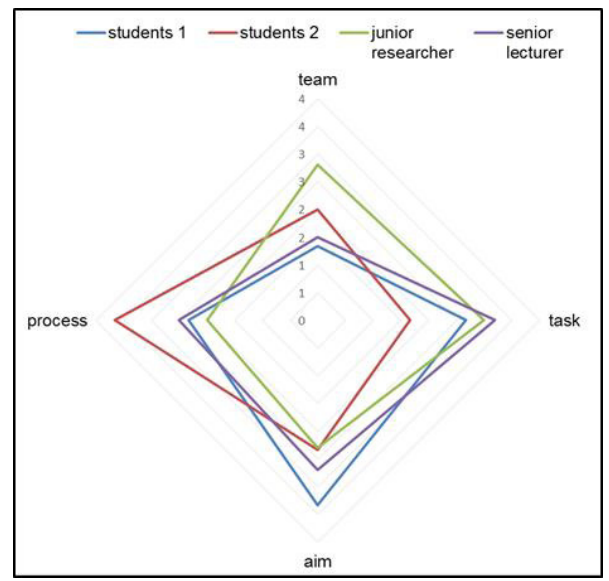

Source: own work.

The diversified results of each group of respondents reflect the complexity of the organisational culture, which limits the usefulness of questionnaires such as Dreimuller's. The structure and university specificity stimulate also the existence of sub-cultures, which may explain the aforementioned differences in perceptions. We will come back to this issue in the 'discussion' paragraph. Before this, though, we would like to refer, at least to a limited extent, to the influence of the national culture on the organisational cultures of the Polish and Dutch university.

\section{Link with national cultures}

One of the sources of organisational cultures is the national culture of the country the company is located in [Schein 2000]. Despite the multiplicity of national culture frameworks, for demonstration purposes we have compared the Dutch and Polish national cultures on the basis of Solomon and Schell [2009]. Table 3 presents this model dimensions indexes for Poland and the Netherlands.

On the basis of Solomon and Schell we would expect that Dutch organisational culture in general, in terms of Dreimüller, is more open to change. Although Solomon and Schell do not give an indication of outwards orientation (internalexternal), the Dutch have always had a very open economy. The two combined we might expect more of the task-orientation on the Dutch culture side and a slight inclination to the process-culture (control, internal) on the Polish side, which actually was demonstrated in our survey. At the same time one may wonder whether such an orientation (control, internal) reflects socialist days and whether the long-term Polish culture is more open. The expressed preference for a team and task-culture indicates a willingness to change and again one may wonder whether that reflects the change towards a pluralist democracy and market oriented economy. 
The Dutch are also much more egalitarian than the Poles and much more direct in their communication. These two dimensions may be explanatory for the dominance of team culture over the aim culture at the Dutch university unit and the opposite result at the Polish university unit. The question is then if the desires for the team culture at the Polish university indicate changes of the Polish national culture towards egalitarianism.

Table 3. Solomon and Schell culture dimensions for Poland and the Netherlands

\begin{tabular}{|l|l|l|l|l|l|}
\hline Dimension & $5-9$ & $10-13$ & $14-17$ & $18-21$ & $22-25$ \\
\hline Egalitarianism - hierarchy & & & & & \\
\hline Individual versus group orientation & & & & & \\
\hline Relations: transactional versus interpersonal & & & & & \\
\hline Direct versus indirect communication & & & & & \\
\hline Low or high value of time & & & & & \\
\hline Change averse - change tolerant & & & & & \\
\hline Motivation: work-life balance versus status & & & & & \\
\hline
\end{tabular}

Legend: $\dddot{W}$ the Dutch national culture

the Polish national culture

Source: Solomon and Schell 2009.

\section{Discussion}

Research of organisational culture cannot be done without cultural biases but not all researchers are aware of the cultural glasses they are wearing. These glasses include national value patterns. One pitfall has hardly been recognised, the effect of values in economic systems. In general terms one might say that the Anglo-Saxon system focuses on shareholder value and the Rhineland model on product and customer. For these reasons foreign, e.g. American, management models often fail if implemented lock, stock and barrel in e.g. the Netherlands or Poland.

The work by Dreimüller suffers from this problem because the author takes the Balanced Score Card, an American approach, as his starting point for outlining organisational cultures in the Netherlands. He does not question the applicability of the BSC outside the USA. However, his research and the one by Hofstede are the rare examples of the European approaches.

Our original idea was to relate the students and staff perceptions of the Polish university unit organisational culture and to compare this with the similar survey 
conducted in the Dutch university unit. Practical consideration (time, permissions) prevented us from doing so and instead we made a study of limited scope but with differentiated ways of the tool usage. On this basis we may draw the following provisional conclusions concerning its utility:

- The questionnaire is just a starting point for much more detailed discussions; hence, it has a relative value. And even if all parties agree on the organisational culture, one needs to decide for what purpose and how this organisational culture will be used; better even if done so beforehand.

- A distinction between management, students, supporting staff, and lecturers is useful in view of the different roles these parties play and the need to optimise their interactions. Limiting the delineation of an organisational culture of a university to its staff, excluding students, considerably reduces the reliability and value of the results.

- Representative samples with large numbers of respondents are necessary conditions for the reliability of the outcome of the questionnaire (which, in turn, is only the first step).

Universities are a specific type of organisation. One may say that the two dimensions of Dreimüller are also two dilemmas for universities. On the one hand, a university is focused on control in terms of rigorous scientific experiments and the development of students, and on the other, on change in terms of ever-new developments that need to be taken into consideration. Internal points to the needs of having one's house in order (e.g. the academic quality) and external to the role of universities in societal debate. Indeed, from this perspective a university is a balancing act. The results of our survey give an impression of organisational cultures of the two analysed universities. As mentioned before, culture research is always biased with the researcher's set of values. Thus, the results gained in each unit may be also rationalised using a perspective of the researcher. In the case of the Polish university the researcher's perspective assumes that, like in the Deal/Kennedy framework, a university performs in a combination of low risk and long-term feedback. This is a dominant notion of specificity and the role played by the university in the Polish system and it implies the process culture type as predominant. Actually this type of culture was indeed identified in the Polish university unit. The Dutch concept of the university is reflected in the two tier structure, academic universities and universities of applied sciences. The former is focused on scientific research, more internal and control or process-culture. The latter focuses on preparing for specific jobs and should be more external and control or aim-culture. However, academic universities have more students than societal needs for scientists and hence, looks at other employment opportunities as well. At the same time universities of applied science are often used as a tool for higher education rather than the preparation for a job. 
Our pilot study revealed both advantages and disadvantages of the Dreimüller's questionnaire. As such it may be considered as a contribution to the organisational culture studies and an introduction to further in-depth analyses. We plan to continue our investigation and hope to share the results in the future.

\section{References}

Ashkanasy N.M., Wilderom C.P.M. and Peterson M.F. (eds) (2000), Handbook of Organizational Culture \& Climate, Thousand Oaks: Sage Publications.

Brown, A. (1998), Organisational culture, London: Pitman Publishing.

Cameron K.S. and Quinn R.E. (2006), Onderzoeken en veranderen van organisatiecultuur, Den Haag: Sdu Uitgevers.

Chaput C., (2008), Inside the Teaching Machine: Rhetoric and the Globalization of the U.S. Public Research University, Tuscaloosa: University of Alabama Press.

Dreimüller, A (2008a), Grip op werkprocessen, HRM en organisatiecultuur, The Hague, Academic Service.

Dreimüller, A (2008b), Het organisatiecultuurspel, The Hague, Academic Service.

Handy, C.B. (1978), The Gods of Management, Harmondsworth: Penguin.

Harrison, R. (1972), 'Understanding Your Organization's Character', Harvard Business Review, 50, Maj-June, pp. 119-128.

Gipp, G.E. and Warner, L.S. (2009), Tradition and Culture in the Millennium: Tribal Colleges and Universities, Charlotte, NC: Information Age Pub.

Hampden-Turner, C. and Trompenaars F. (1997), Riding the Waves of Culture: Understanding Diversity in Global Business, McGraw-Hill.

Hofstede, G., Hofstede G.J. and Minkov, M. (2010), Cultures and Organizations, Software of the Mind, Intercultural Cooperation and Its Importance for Survival, New York, McGraw-Hill.

Martin J. (1992), Cultures in Organizations, Three Perspectives, Oxford University Press.

Nispen tot Pannerden, P.J.M. van (2011), 'Handling Culture', Journal of Positive Management, vol. 2, no.1, pp. 59-74.

Sanders, G., B., and Neuijen (2005), Bedrijfscultuur; diagnose en beïnvloeding. Assen, Nederland: Van Gorcum.

Schein, E.H. (2000), De bedrijfscultuur als ziel van de onderneming; zin en onzin over cultuurverandering, Schiedam: Scriptum Management.

Schwartz, SH. (1992), Universals in the content and structure of values: Theoretical advances and empirical tests in 20 countries, San Diego: Acacemic Press.

Solomon, C.M. and Schell, M.S. (2009), Managing across Cultures, The Seven Keys to Doing Business with a Global Mindset, New York: McGraw Hill.

Vroom, C. (2002) 'Kan het wel anders? Over de mogelijkheid van veranderen', in Nispen tot Pannerden, P. van, Vroom, C., Wagenaar, R. en Wouters, P. (ed.): Anders in verandering, Utrecht, Lemma 


\section{Appendix}

\begin{tabular}{|c|c|}
\hline \multicolumn{2}{|c|}{ THE ORGANISATION } \\
\hline R1 & The organisation is \\
\hline A & Familiar. The member do and share a lot with one another. \\
\hline B & Dynamic. Risks are taken, entrepreneurship may be noticed. \\
\hline $\mathrm{C}$ & $\begin{array}{l}\text { Result oriented. The objective needs to be met and strong } \\
\text { mutual competition occurs. }\end{array}$ \\
\hline $\mathrm{D}$ & $\begin{array}{l}\text { Structured, formal rules and procedures and strict manage- } \\
\text { ment are characteristic. }\end{array}$ \\
\hline $\mathrm{R} 2$ & The organisation is mainly focused on \\
\hline A & $\begin{array}{l}\text { Collegiality, safety, transparency and involvement in the objec- } \\
\text { tive of the organisation. }\end{array}$ \\
\hline B & $\begin{array}{l}\text { Looking for, developing and implementing new things (prod- } \\
\text { ucts, clients and means). }\end{array}$ \\
\hline $\mathrm{C}$ & $\begin{array}{l}\text { Internal competition, aggression, realising objectives and win- } \\
\text { ning. }\end{array}$ \\
\hline $\mathrm{D}$ & $\begin{array}{l}\text { Rules, procedures, efficient production and maintaining the } \\
\text { status quo. }\end{array}$ \\
\hline R3 & The success of the organisation is determined by \\
\hline A & $\begin{array}{l}\text { Personnel development through involvement of and care for } \\
\text { people. }\end{array}$ \\
\hline B & The availability of unique, innovative, leading new products. \\
\hline $\mathrm{C}$ & Being ahead of the competition and a larger market share. \\
\hline $\mathrm{D}$ & $\begin{array}{l}\text { Efficient, functional, reliable, cheap, well organised and con- } \\
\text { trolled production. }\end{array}$ \\
\hline $\mathrm{R} 4$ & The organisation treats people in the organisation as \\
\hline A & $\begin{array}{l}\text { Family or friends who like being together and want to support } \\
\text { one another. }\end{array}$ \\
\hline B & Equals who unanimous aim at a common goals. \\
\hline $\mathrm{C}$ & Means, which can be used by management. \\
\hline $\mathrm{D}$ & Employees with a contract and mutual rights and duties. \\
\hline $\mathrm{TH}$ & \\
\hline R5 & The management of the organisation \\
\hline A & $\begin{array}{l}\text { Guides, supports, stimulates, facilitates and cares for employ- } \\
\text { ees. }\end{array}$ \\
\hline
\end{tabular}




\begin{tabular}{|c|c|}
\hline B & $\begin{array}{l}\text { Shows entrepreneurship, takes risks and is focused on innova- } \\
\text { tion and renewal. }\end{array}$ \\
\hline $\mathrm{C}$ & $\begin{array}{l}\text { Does not like nonsense, is aggressive and wants to realise ob- } \\
\text { jectives. }\end{array}$ \\
\hline $\mathrm{D}$ & $\begin{array}{l}\text { Arranges, is focused on the process, co-ordinates and stream- } \\
\text { lines production. }\end{array}$ \\
\hline R6 & The management is expected to \\
\hline A & Be concerned for the employees and be aware of their needs. \\
\hline B & $\begin{array}{l}\text { Listen, to start the dialogue and to be open for ideas of em- } \\
\text { ployees. }\end{array}$ \\
\hline $\mathrm{C}$ & Be strong and decisive, hard but just. \\
\hline $\mathrm{D}$ & $\begin{array}{l}\text { Is impersonal, manages only and does not aim for personal } \\
\text { profit. }\end{array}$ \\
\hline R7 & The management focuses on \\
\hline A & $\begin{array}{l}\text { Strong mutual relations, team-work, consensus and participa- } \\
\text { tion. }\end{array}$ \\
\hline $\mathrm{B}$ & Offering freedom, taking risk oneself for finding innovation. \\
\hline $\mathrm{C}$ & $\begin{array}{l}\text { External and internal competition, high demands, efforts and } \\
\text { results. }\end{array}$ \\
\hline $\mathrm{D}$ & Clarity, rules, regulations, procedures and stable relations. \\
\hline $\mathrm{R} 8$ & You may say to another what needs to happen if \\
\hline A & The other has asked for help, guidance or advice. \\
\hline $\mathrm{B}$ & You have more knowledge and experience. \\
\hline $\mathrm{C}$ & You have a higher position. \\
\hline $\mathrm{D}$ & It is mentioned in the job description. \\
\hline TH & \\
\hline R9 & People need to give priority to \\
\hline A & $\begin{array}{l}\text { The common implementation of tasks and the mutual support } \\
\text { in doing so. }\end{array}$ \\
\hline $\mathrm{B}$ & $\begin{array}{l}\text { The implementation of their task and finding better ways of } \\
\text { doing that. }\end{array}$ \\
\hline $\mathrm{C}$ & The assignments, questions and desires of their superiors. \\
\hline $\mathrm{D}$ & $\begin{array}{l}\text { The implementation of their tasks within the existing rules and } \\
\text { procedures. }\end{array}$ \\
\hline
\end{tabular}




\begin{tabular}{|c|c|}
\hline R10 & People performing well are those who \\
\hline A & $\begin{array}{l}\text { Have a caring and co-operative attitude and work on good rela- } \\
\text { tions. }\end{array}$ \\
\hline B & Are professionals and want to get the job done. \\
\hline $\bar{C}$ & Know how they can use their power to satisfy their superior. \\
\hline $\mathrm{D}$ & $\begin{array}{l}\text { Implement their work within the system according to the } \\
\text { prevalent rules. }\end{array}$ \\
\hline R11 & Employees are expected to \\
\hline A & Good team players and have good contacts with one another. \\
\hline B & $\begin{array}{l}\text { Realise their tasks in a motivated and competent way and re- } \\
\text { alise improvements accordingly. }\end{array}$ \\
\hline $\mathrm{C}$ & Be hard working, obedient and loyal to the management. \\
\hline $\mathrm{D}$ & $\begin{array}{l}\text { Doing their job in a responsible and reliable way and prevent- } \\
\text { ing aberrations }\end{array}$ \\
\hline R12 & People are motivated by \\
\hline A & $\begin{array}{l}\text { The need for co-operation and the maintenance of good work- } \\
\text { ing relations. }\end{array}$ \\
\hline B & $\begin{array}{l}\text { Their own motivation, the wish to contribute and by thinking } \\
\text { of improvements. }\end{array}$ \\
\hline $\mathrm{C}$ & The hope of [extra) reward or the prevention of sanctions. \\
\hline $\mathrm{D}$ & Expectation of a reasonable reward for a reasonable effort. \\
\hline \multicolumn{2}{|c|}{ THE DECISION-MAKING } \\
\hline R13 & Decisions are \\
\hline A & $\begin{array}{l}\text { The result of agreement, acceptance and support by the em- } \\
\text { ployees. }\end{array}$ \\
\hline B & $\begin{array}{l}\text { Taken as much as possible at the lowest level by people on the } \\
\text { work-floor. }\end{array}$ \\
\hline $\mathrm{C}$ & $\begin{array}{l}\text { Taken on the basis of orders and instructions by the manage- } \\
\text { ment. }\end{array}$ \\
\hline $\mathrm{D}$ & $\begin{array}{l}\text { Fit within the agreed upon frameworks after going through the } \\
\text { agreed upon procedures. }\end{array}$ \\
\hline R14 & If rules and procedures are getting in the way \\
\hline A & $\begin{array}{l}\text { People support one another by a wider interpretation of the } \\
\text { rules and procedures. }\end{array}$ \\
\hline $\mathrm{B}$ & They are neglected. \\
\hline
\end{tabular}




\begin{tabular}{|l|l|}
\hline C & $\begin{array}{l}\text { They are violated if one has the power to do so or does not } \\
\text { expect punishment. }\end{array}$ \\
\hline D & $\begin{array}{l}\text { They are followed nevertheless or one requests to adapt the } \\
\text { rules and procedures. }\end{array}$ \\
\hline R15 & The assignment of tasks or works is based upon \\
\hline A & $\begin{array}{l}\text { The personal preferences of the employee (career) and in con- } \\
\text { sultation. }\end{array}$ \\
\hline B & $\begin{array}{l}\text { The mutual co-ordination of work and the qualities of the } \\
\text { employee. }\end{array}$ \\
\hline C & The judgement of the superior. \\
\hline D & $\begin{array}{l}\text { The plans of van the organisation in accordance with the exist- } \\
\text { ing rules. }\end{array}$ \\
\hline R16 & Conflicts are normally \\
\hline A & $\begin{array}{l}\text { Solved to maintain the good working atmosphere and without } \\
\text { hurting people. }\end{array}$ \\
\hline B & Solved by discussions, aimed at finding win-win solutions. \\
\hline C & Solved by management. \\
\hline
\end{tabular}

